
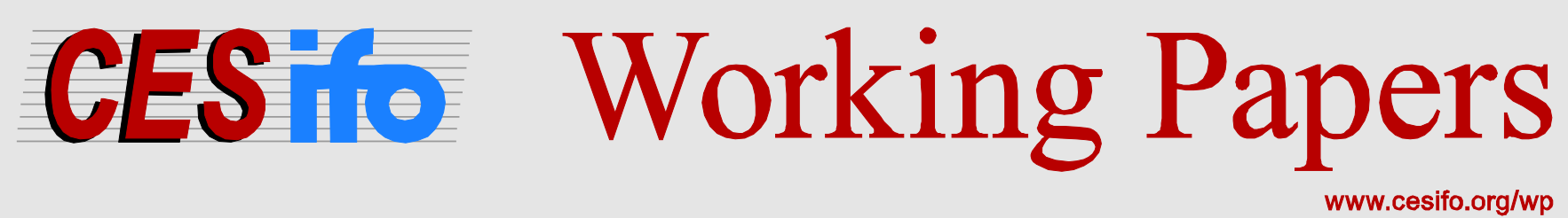

\title{
Who Participates in Tax Avoidance?
}

\author{
Annette Alstadsæter \\ Martin Jacob
}
CESIFO WORKING PAPER NO. 4219
CATEgory 1: PubliC FinANCE
APRIL 2013

An electronic version of the paper may be downloaded

- from the SSRN website:

- from the RePEc website:

- from the CESifo website:

WWw.SSRN.com

www.RePEc.org

www.CESifo-group.org/wp

\section{CESifo}




\title{
Who Participates in Tax Avoidance?
}

\begin{abstract}
This paper analyzes the sources of heterogeneity in legal tax avoidance strategies across individuals. Three conditions are required for a taxpayer to participate in tax avoidance: incentive, access, and awareness. Using rich Swedish administrative panel data with a unique link between corporate and individual tax returns, we analyze individual participation in legal tax planning around the 2006 Swedish tax reform. Our results suggest that closely held corporations are utilized to facilitate income shifting across tax bases to reduce the individual's overall tax burden. We find that both tax incentives and awareness of tax incentives impact the decision to access income-shifting opportunities. Our results show that factors explaining participation in legal tax avoidance substantially differ from those explaining participation in illegal tax evasion.
\end{abstract}

JEL-Code: H200, H240, H250, H260.

Keywords: tax avoidance, income shifting, income taxation, dividend taxation.

Annette Alstadsceter

Institute of Health Management and

Health Economics / University of Oslo

P.O. Box 1089 Blindern

Norway - 0317 Oslo

annette.alstadsater@medisin.uio.no
Martin Jacob

WHU - Otto Beisheim School of

Management

Burgplatz 2

Germany - 56179 Vallendar

martin.jacob@whu.edu

April 15, 2013

We are grateful to Kay Blaufus, Lisa De Simone, Karin Edmark, Martin Fochmann, Jochen Hundsdoerfer, Adrian Kubata, Diderik Lund, Axel Möhlmann, Jukka Pirttilä, Ulrich Schreiber, Jan Södersten, Bridget Stomberg, Erin Towery, Altin Vejsiu, and seminar participants at the WHU - Otto Beisheim School of Management, Center for European Economic Research (ZEW) in Mannheim, Spring Meeting of the Tax Section of the German Academic Association for Business Research, Research Institute of Industrial Economics (IFN) in Stockholm, Oslo Fiscal Studies, University of Mannheim, University of Muenster, University of Magdeburg, and Uppsala Center for Fiscal Studies, for helpful comments and suggestions. We thank Statistics Sweden (SCB) and Barbro Olsson for excellent assistance with the data. Financial support from the Research Council of Norway, grant 17139/H20, is gratefully acknowledged. 


\section{Introduction}

Recent empirical studies suggest that there is substantial heterogeneity in the uptake of incentives to participate in tax avoidance strategies across individuals. Both access to evasion and potential punishment upon detection explain why not everyone evades taxes (Kleven, Knudsen, Kreiner, Pedersen, and Saez, 2011). Yet, these explanations do not necessarily hold for legal tax avoidance that carries no risk of penalty. Still, very little is known about whether participation in illegal tax evasion and legal tax avoidance are driven by the same factors. A question stands as to why not all individuals participate in legal tax avoidance.

Three conditions are required for a taxpayer to participate in legal tax avoidance. We categorize these conditions as incentive, access, and awareness. First, the taxpayer must have an incentive to participate in tax avoidance. That is, the tax benefit from tax avoidance must outweigh its costs. Second, the taxpayer needs access to tax-minimizing strategies. For example, employees generally have less opportunity to shift income across tax bases than owner-managers of closely held corporations. Finally, the taxpayer must have awareness of the tax code, of the incentive to minimize taxes, and of the opportunities available to do so. ${ }^{1}$

As argued by Slemrod and Yitzhaki (2002), the distinction between legal tax avoidance and illegal tax evasion is often blurred, because of either ambiguous laws or a lack of focus on particular types of transactions by tax authorities. The main challenge for empirical studies on participation in tax avoidance is the lack of convincing individual income tax data that allows both control of demographic characteristics and observation of legal tax avoidance behavior. In this analysis, we focus on legal tax avoidance strategies of individuals that can be observed in the micro data.

We employ a rich administrative panel data set from Sweden to analyze sources of heterogeneity involved in participation in observable income shifting. Income shifting is defined as the legal process of relabeling existing income or assets in order to reduce total tax payments. ${ }^{2}$ Our

\footnotetext{
${ }^{1}$ We have encountered first-hand, anecdotal evidence on the importance of awareness. Several seminar participants told us after having listened to our presentation, i.e., after becoming aware, that they will follow the tax avoidance strategies outlined in this paper.

${ }^{2}$ The main types of income shifting are across time, across tax bases, and across taxpayers (Stiglitz, 1985). Income shifting across time can involve deferral of capital gains realization (Ivković, Poterba, and Weisbenner, 2005) or the timing of dividend payouts (Chetty and Saez, 2005; Jacob and Jacob, 2012). Income shifting across tax bases involves reclassification of labor income as capital income through choice of organizational
} 
panel data set for the years 2000-2008 contains the tax returns of all corporations in Sweden, along with income tax returns and demographic information from a representative panel of $6.6 \%$ of the Swedish population. Using a unique link from the corporate to the individual level, we are able to identify owners of corporations and to link information across data sets. This allows us to identify corporations designed for tax avoidance purposes and to link this characteristic to the individual owner level. Using this link, we are able to observe the socioeconomic characteristics of individuals participating in income shifting.

With a progressive tax on labor income and a proportional tax on capital income, the Swedish dual income tax incentivizes income shifting from the labor income tax base to the capital income tax base. In particular, owner-managers of closely held corporations can determine how much to distribute as wages or dividends to themselves. To prevent this type of tax avoidance, Sweden limits the amount of dividends from closely held corporations that are taxed at the proportional tax rate. This limit - the dividend allowance - depends on equity and wages costs. Empirical identification of income shifting is based on the 2006 tax reform, which, to foster entrepreneurship and simplify compliance, cut the tax rate on dividends to active owners of closely held corporations (CHC) from $30 \%$ to $20 \%$. At the same time, the dividend allowance was increased substantially and an alternative allowance, independent of activity and equity in the firm, was introduced. This brought about two effects on tax avoidance incentives. First, the reform promotes income shifting from the labor to the capital income tax base. Second, the tax wedge between dividend income from $\mathrm{CHC}$ and widely held corporations (WHC) sets an incentive to shift assets and shares to the CHC level to defer and to reduce dividend and capital gains taxes. Neither of the two tax avoidance effects induced by the reform - shifting income from the labor to the capital income tax base and shifting income within the capital income tax base - were intended by the tax authorities. We use this tax reform as a natural experiment to analyze heterogeneity across individuals in their participation in these two types of legal tax avoidance.

form of a firm and wage-dividend payout (Romanov, 2006; Thoresen and Alstadsæter, 2010; Elschner, 2013). Income shifting across taxpayers includes intrafamily transfer of income and assets (Stephens and Ward-Batts, 2004). See Alstadsæter and Jacob (2012) for a discussion of the concept of income shifting and a review of the literature. 
We define an individual as an income shifter if he actively participates in: (i) a holding corporation, (ii) a low-turnover corporation, or (iii) a shell corporation. A holding corporation enables individuals to shift income within the capital income tax base, that is, to re-label dividends from a WHC as lower-taxed dividends from a CHC. A low-turnover corporation can be established to channel labor income through the corporation to benefit from the tax wedge between labor and capital income. However, such a firm could also be used to generate additional income. Our empirical results suggest that these firms are indeed used to shift existing income and not for income generation. A shell corporation is a tax avoidance tool that serves as an option for future tax savings. If the individual expects high income streams in the future, the individual has incentives to establish a shell corporation to accumulate and forward unused dividend allowances, to facilitate future income shifting. We find that the uptake of holding, shell, and low-turnover corporations increased substantially after the 2006 reform. For example, we classify more than one-fifth of all newly founded CHC in 2006 as holding companies. In total, more than $25 \%$ of all new firms established after 2006 meet our income-shifting criteria - an increase of over 11 percentage points compared to the pre-reform average.

The first part of this paper documents income shifting through holding, low-turnover, and shell corporations. Using a difference-in-difference approach around the 2006 reform, we find that individuals who establish low-turnover firms substitute labor income with capital income to reduce the overall income tax burden. At the same time, these individuals do not generate higher before-tax income. This result holds even when taking into account revenues and turnover from the corporation in calculating individual before-tax income. We further find that owners of holding corporations reclassify ordinary capital income as tax-favored dividends from a CHC around the 2006 tax reform. Again, we find no before-tax total income effect. These findings are consistent with tax avoidance behavior and show that having access to firms designed for income shifting leads to substitution of more highly taxed income with lower taxed income.

The second part analyzes the heterogeneity in participation in income shifting. Not all individuals with a tax incentive to invest in a tax sheltering firm do so. For example, even 
though about $17 \%$ of employed individuals would benefit from shifting labor income to capital income (2005 values), less than $0.5 \%$ of taxpayers have a low-turnover corporation. Our unique data set enables us to identify the demographic and socioeconomic factors that characterize individuals participating in income shifting. Using a two-stage selection model that controls for being a CHC owner-manager, we find that incentives, access, and awareness matter in the decision to pursue income shifting. We find evidence of substantial effects from socioeconomic variables on income shifting. ${ }^{3}$ Highly taxed individuals are more likely to be an owner in a CHC designed to access income-shifting opportunities. Having a university education, particularly a business degree, has a substantial positive effect on the likelihood of participating in tax avoidance. Individuals with a business degree have a 4.5 percentage point higher likelihood of participating in a holding corporation-about $77 \%$ of the unconditional mean. We also employ a more exogenous measure of tax awareness. Individuals born in Sweden generally have fewer language difficulties in understanding the tax code and tax incentives. Consistent with this notion, we find that Swedish-born individuals are significantly more likely to participate in income shifting. We also find a significant effect from age and gender on income shifting. Finally, our results indicate that individuals with easier access to income shifting, such as consultants and accountants, are more likely to invest in tax sheltering firms than individuals with limited access to income shifting, such as public employees. This is a strong indication that awareness and access explain part of the heterogeneity in participation in income shifting across individuals.

The third part of this study examines more closely the impact of incentives and awareness on tax avoidance activity. This section also addresses concerns over our proxies. We operationalize the tax incentive with a dummy variable equal to 1 if an individual's income is above the first state tax threshold. Above this threshold, the marginal income tax increases by 20 percentage points. Individuals with income below this threshold do not have a tax incentive to re-label labor income as capital income, while individuals above this threshold do have such incentive. We run local linear regressions around the kink to identify the tax effect. Using very

\footnotetext{
${ }^{3}$ This finding differs from studies on corporate tax avoidance. Dyreng, Hanlon, and Maydew (2010) show that managers have an impact on firm tax avoidance. Yet, these authors cannot identify common, observable individual characteristics that explain executives' propensity to reduce effective corporate tax rates.
} 
narrow bands around the state tax threshold, our results from these local linear regressions confirm a substantial economic effect from taxes on tax avoidance activities. Crossing the state tax threshold in the prior year increases the likelihood of owning a shell corporation by 1.6 percentage points, or about $100 \%$ of the unconditional mean. This surprisingly large effect can be explained by the salience of the kink (Chetty, Looney, and Kroft, 2009). Individuals below the threshold pay only municipality tax. Individuals above the kink pay municipality and state tax. These two income taxes have different names that make the marginal tax rate increase very visible. Next, we address concerns that our tax awareness measures: age, education, and country of birth are correlated with other variables and may thus be poor proxies for awareness of tax planning opportunities. Alstadsæter, Kopczuk, and Telle (2012) find that participation in tax avoidance spreads through social networks. We build upon this notion and use crossmunicipality differences in the density of tax avoidance activities as a proxy for awareness. If more individuals in a municipality participate in a firm designed for tax avoidance purposes, information spreads more easily and other individuals in the same municipality are more likely to participate in income shifting as well. We find evidence in favor of this prediction. The percentage of individuals owning a firm designed for tax avoidance in a municipality positively affects the likelihood that an individual establishes a new income shifting firm in the following year.

This paper contributes to the empirical literature on the determinants of tax minimization, including the effects of tax incentives and demographic characteristics. Our results point toward substantial differences in the effect of tax incentives and socioeconomic variables on illegal tax evasion on the one hand, and on legal tax avoidance on the other. Kleven, Knudsen, Kreiner, Pedersen, and Saez (2011) find no effects of tax rates on participation in tax evasion by selfemployed individuals. Higher education and age seem to have a negative effect on participation in tax evasion. In contrast to illegal tax evasion, we find a strong and positive effect from tax rates, education, and age on participation in legal tax avoidance. Gender points in the same direction for tax evasion and for tax avoidance: Women are less likely to participate in any form of tax minimization. 
Our results have important policy implications. If mainly high-income individuals benefit from tax incentives, income inequality increases and vertical equity is reduced. In addition, horizontal equity is reduced, as only informed individuals with awareness of tax changes and access to income shifting react to tax incentives. This is relevant for tax authorities when designing and communicating tax reforms. If tax rules are overly complex and the resulting incentives are not transparent, unintended effects can occur if awareness of incentives is concentrated among informed, highly taxed individuals.

The remainder of the paper is organized as follows. In Section 2, we discuss the relevant literature and provide a theoretical background for our analysis. In Section 3, we describe the Swedish tax system, the tax reform of 2006, and the resulting incentives. Section 4 describes the data and variables. In Section 5, we present our empirical results. Finally, Section 6 sets forth our conclusions.

\section{Related literature and heterogeneity in participation in tax minimization}

Recent empirical research documents heterogeneity in participation in tax minimization. The question is, why do not all taxpayers participate in tax evasion or avoidance? We argue that there are three main reasons for this: First, in order to participate in tax-minimizing strategies, the taxpayer must have an incentive to do so. Second, the taxpayer needs access to taxminimizing strategies. Finally, the taxpayer requires awareness of the tax code as well as the incentives and income-shifting opportunities available. We simultaneously test the effects of incentive, access, and awareness on participation in tax avoidance across individuals. Let us now discuss each of these conditions in detail.

\subsection{Incentive for tax minimization}

Individuals participate in legal tax avoidance if the expected benefits exceed the costs associated with tax avoidance. The benefit of tax minimization is the expected reduction in tax payments, and thus an increase in disposable income. In turn, the costs of tax minimization can include monetary outlays to obtain access to the tax-minimizing strategy, e.g., fees for tax consultants, 
cost of time spent pursuing tax-minimizing strategies, and other non-pecuniary costs such as tax morale (Andreoni, Erard, and Feinstein, 1998; Fortin, Lacroix, and Villeval, 2007).

Because of a general lack of suitable data, few studies analyze the effects of incentives on participation in tax minimization and the reasons for observed heterogeneity across individuals. There is, however, a sizable and growing literature on income shifting through choice of organizational form by owner individuals. High-income individuals change the organizational form of their businesses to reduce their total tax burden (see, for example, Gordon and Mackie-Mason, 1994; Romanov, 2006; Elschner, 2013). A substantial literature evaluates the responses of taxable income to tax changes or changing incentives, as surveyed by Saez, Slemrod, and Giertz (2012). Kopczuk (2012) documents increases in reported income in response to an optional new tax rule that increased incentives for many taxpayers to declare income, thus weakening the tax incentives for underreporting income.

\subsection{Access to tax minimization}

Access to tax-minimization strategies is a second important source of heterogeneity in participation in tax minimization. In many cases, several actions are necessary to participate in tax avoidance, for example, setting up a holding company, becoming self-employed (for example, Kleven, Knudsen, Kreiner, Pedersen, and Saez, 2011; Pirttilä and Selin, 2011; Shaw, Slemrod, and Whiting, 2010), or owning stock options (Goolsbee, 2000). An owner-manager of his own firm can determine the tax-minimizing combination of compensation across wage and capital income. In contrast, employed individuals have fewer opportunities to shift income; they need to negotiate with their employer, for example, on compensation via a stock compensation plan. This reduces not only the available income-shifting opportunities, but also increases the costs associated with income shifting for employed taxpayers.

Likewise, access to tax evasion, in particular to underreporting income, also depends on who reports the income and who remits the taxes (see, for example, Kopczuk and Slemrod, 2006; Kleven, Knudsen, Kreiner, Pedersen, and Saez, 2011). Third-party reporting limits access to underreporting income for ordinary wage earners, as the employer remits taxes on behalf of the employee. This removes the opportunity for ordinary wage earners not to pay wage income 
taxes (Shaw, Slemrod, and Whiting, 2010). In countries with third-party reporting of income and withholding taxes, access to tax evasion is thus restricted to taxpayers that self-report their income, such as self-employed individuals. However, even among those with the opportunity to evade, only about 40\% actually do so (Kleven, Knudsen, Kreiner, Pedersen, and Saez, 2011).

\subsection{Awareness of tax minimization}

A growing literature also emphasizes tax awareness as a source of heterogeneity in participation in tax minimization. The taxpayer's awareness of tax rules depends on the salience of taxes, on the accessibility of information about the tax system, and on the individual's ability to process information. If there is only third-party reporting of income, and if the employer or other institutions such as banks remit the taxes, tax payments become less salient. This reduces awareness of how much taxes individuals actually pay (Chetty, Looney, and Kroft, 2009; Finkelstein, 2009). As a consequence, individuals may be unaware of the incentive to participate in tax-minimizing strategies. For example, Slemrod, Blumenthal, and Christian (2001), surprisingly, find indications of increased tax minimization among high-income individuals following a written audit threat. The audit letter appears to raise the awareness of tax payments and, subsequently, increases participation in tax minimization. Slowness in adapting to changing income levels may also explain why not all individuals respond to tax incentives (Jones, 2012). Similarly, Kopczuk (2007) suggests that procrastination is one reason why not all individuals participate fully in legal estate tax planning. Further, the ability to process the available information varies across individuals, as does the flow of information through individual networks. Alstadsæter, Kopczuk, and Telle (2012) conclude that informal spreading of information within the family is important to participation in tax-avoidance strategies. 


\section{Incentives for income shifting}

\subsection{Tax rules for labor and capital income, and the 2006 tax reform in Sweden}

We next discuss the structure of the Swedish tax system and of income-shifting incentives in detail. Sweden has a dual income tax, with progressive taxes on labor income and a proportional tax on capital income. This system was implemented in 1991. The progressivity of the tax on labor income is achieved through a basic flat municipality tax and two additional state taxes that apply at different thresholds. Table 1 is an overview of developments in top marginal tax rates and thresholds for the period 2000-2008.

\section{[Insert Table 1 about here]}

The difference between the top marginal tax rates on labor and capital income creates strong incentives to reclassify wage income as dividend income for individuals subject to the state tax. Ordinary wage earners have little access to this type of income shifting. In contrast, active owners of smaller firms can decide how to distribute firm profits as wages or dividends. In the most extreme scenario, all wage earners could start their own firms and pay out the compensation for their labor effort as the least-taxed income source.

Sweden's so-called 3:12 rules are designed to prevent such income shifting by firm owners. According to these rules, dividends to active owners ${ }^{4}$ of $\mathrm{CHCs}^{5}$ are taxed as dividends only up to a particular limit - the imputed dividend allowance. This dividend allowance is a function of the equity and wage costs of the corporation (general imputation method). ${ }^{6}$ Dividends in excess of the dividend allowance are taxed as labor income. The dividend allowance is calculated by the individual for each firm according to ownership share in the corporation. Any unused dividend allowances are carried forward with interest.

\footnotetext{
${ }^{4} \mathrm{~A}$ shareholder is active if he contributes to profit generation in the firm to a considerable extent. This is not precisely defined in the tax law, and because of an apparent lack of control by the tax authorities, it would appear that, in practice, the owner can define himself as active and still come under the 3:12 rules should the owner so choose, independent of the level of activeness.

${ }^{5}$ The tax law defines a corporation as closely held if 4 or fewer shareholders own at least $50 \%$ of the shares. Multiple family members count as a single shareholder. If these criteria are not met, the corporation is considered a WHC. There are no differences in taxation at the corporate level between WHCs and CHCs. Differences in tax treatment occur at the shareholder level.

${ }^{6}$ For a detailed overview on the 3:12 rules and the definition of the dividend allowance, see Alstadsæter and Jacob (2012), Chapter 3 and Appendix I.
} 
In 2006, the 3:12 rules were reformed to foster entrepreneurship and growth of privately held firms. The reform included an increase in the dividend allowance and a reduction in the tax rate on dividends within the dividend allowance. The reform effectively cut tax rates and narrowed tax bases for CHCs in three ways. First, the marginal tax rate on dividends within the dividend allowance was reduced from $30 \%$ to $20 \%{ }^{7}$ Second, the dividend allowance calculated under the general imputation rule increased. Third, an optional, fixed dividend allowance per firm (the simplification rule), independent of activity, equity, and employment in the firm was introduced. ${ }^{8}$ Approximately $80 \%$ of active owners under the 3:12 rules chose the simplification rule to calculate the dividend allowance after 2006.

\subsection{Incentives for participation in income shifting}

As soon as an individual is subject to the state income tax, there are strong incentives to reclassify labor income as capital income. The 2006 reform further increased these incentives, as the tax rate on dividends to active owners of closely held corporations was reduced, the dividend allowance was increased, and the opportunity arose to accumulate dividend allowances under the simplification rule with no or little activity in the firm. We consider three particular types of corporation that appear to be designed for the purpose of legally reducing the tax burden on a given income with no substantial income generating activity.

All three of these tax avoidance methods, designed to facilitate access to shifting income, are legal. There is no audit risk that may influence any of these decisions. Everyone is free to establish a corporation. The minimum required equity amount was SEK 100,000 (about USD 13,550 in 2006) during our sample period. All corporations were additionally required to file balance sheets and income statements, with expected annual costs for accountants amounting

\footnotetext{
${ }^{7}$ Before the reform, owners of CHCs were entitled to a small tax-exempt dividend (Lättnadsregeln). This tax-exempt dividend was limited to $70 \%$ of the interest rate on government bonds, which varied between $4 \%$ and 5\% during over the 2001-2005 period. The dividend allowance for taxable dividends amounted to the interest rate on government bonds plus seven percentage points and a wage base allowance. In total, the dividend allowance for taxable dividends was well above the allowance for tax-exempt dividends. Thus, it is reasonable to assume that the tax reform indeed led to a tax decrease even in the average tax rate.

${ }^{8}$ During our sample period, the dividend allowance from the simple rule has gradually increased from 64,950 Swedish krona (SEK) in 2006 to SEK 91,800 in 2008.
} 
to approximately SEK 10,000. We now present the three tax avoidance strategies that we analyze in this paper. ${ }^{9}$

\subsubsection{Holding corporation: Income shifting across types of capital income}

A holding corporation is established for the purpose of owning assets and shares in other corporations at the corporate level instead of the individual level. Apart from organizational reasons, there are clear tax incentives that favor operating a holding corporation. As of 2004, dividend income and capital gains from WHCs are tax-exempt at the corporate level. ${ }^{10}$ Individuals can thus defer dividend and capital gains taxes until they decide to distribute these funds from the holding company. This is particularly important for minority shareholdings in unlisted corporations, where the minority owner has less control over dividend payout policy. As of 2006, holding companies additionally allow individual shareholders to reduce the tax rates on dividends from WHCs from $30 \%$ (if listed) or 25\% (if unlisted) to $20 \%$ if capital income is channeled through a closely held holding company. The organizational, non-tax motivation for founding a holding company did not change in 2006. Hence, any behavioral response or change in individual characteristics around the tax reform can be attributed to tax reasons.

We define a corporation as a holding company if the main source of income and turnover arises from financial income (dividends and profit distributions) from affiliated companies. In our data, we assign the attribute "holding company" to firms where at least $80 \%$ of the corporation's turnover arises from financial income.

\subsubsection{Low-turnover corporation: Income shifting across income categories, from labor income to capital income}

High-income wage earners have incentives to channel parts of their wage income through a side business organized as a closely held corporation. By re-classifying wage income in excess of the state tax threshold as dividend income, the marginal tax burden can be reduced from about

\footnotetext{
${ }^{9}$ One possible concern is tax rule uncertainty in Sweden. Individuals may be reluctant to take up these income shifting incentives if the rules change frequently. Swedish tax law, however, has proven to be very stable. The dual income tax was introduced in 1991 and there is no discussion of abandoning the present system. Further, the 3:12 rules may have experienced minor adjustments over time, but a change in incentives with a tax rate cut, as in 2006, was a unique occurrence in the past two decades.

${ }^{10}$ For shares in listed firms, dividends and capital gains are tax exempt only if the company holds $10 \%$ or more of the voting rights or if the shares are held for organizational purposes. Therefore, a holding company does not work as a tax avoidance tool for portfolios of listed stocks.
} 
$51 \%$ to the combined marginal tax rate on dividends from CHCs of $42.4 \%$ (as of 2006). If an individual is in the top tax bracket, the combined tax burden on labor income (social security tax and income tax) increases to about $67.2 \%$. Anecdotal evidence suggests that high-income individuals, consultants in particular, create firms for side business or anticipated business. Whether these firms are used for income shifting or generation of additional income is an empirical question addressed in Section 5.2. We define a firm as a low-turnover firm if average turnover is below SEK 200,000 (about USD 27,100), average wages are less than SEK 100,000, and if the firm is not a holding corporation.

\subsubsection{Shell corporation: Option for income shifting from labor income to capital income}

The third tax avoidance tool is the shell corporation. The purpose of the shell corporation is to accumulate unused dividend allowances under the simplification rule and to forward these with interest. The possibility to accumulate and forward unused dividend allowance represents an option value on expected future tax savings. This provides incentives to found companies mainly for the purpose of accumulating dividend allowances. Due to high dividend allowances under the simplification rule beginning in 2006 and the reduced dividend tax rate, the option value increased considerably after that year. In our data, we define a firm as a shell company if it has no turnover and if the firm is not a holding corporation.

However, this definition is apparently at odds with the legal definition of an active owner, as there is no profit generation. Yet, we observe that owners of these firms claim and accumulate dividend allowances over a period of years. This behavior is, surprisingly, not regarded as tax evasion by the Swedish tax administration.

\section{Data and summary statistics}

\subsection{Data sources}

We use the Firm Register and Individual Database (FRIDA) provided by Statistics Sweden. This data set is a combination of three main data sources: corporate tax statements, income tax statements, and the so-called K10-Form. Each owner of a CHC files a K10 for each CHC 
in which the owner actively participates. This filing requirement enables us to link corporate tax data and individual tax returns. Figure 1 illustrates the linking procedure.

Insert Figure 1 about here

The first data set comprises a full sample of all corporations registered in Sweden for the period 2000-2008 (referred to as the Corporate Tax Data). The corporate tax data are a panel data set based on corporate tax returns from the obligatory $I N K 2$ form filed by all listed and unlisted corporations. ${ }^{11}$ The tax returns include information on tax balance-sheet items and the profit and loss statement. The raw data contain 442,772 firms and 2,904,123 firm-year observations for the period 2000-2008. We make several sample adjustments. First, we drop observations where a corporation filed two or more tax statements in a single year. We further exclude firm-years with negative total assets, nominal capital, sales, turnover, or scheduled depreciation, and observations where information on dividends, share capital, and organizational form is missing. Finally, we exclude central banks, funds, foundations, and government-owned entities. This yields a final sample of 426,949 firms and 2,736,747 firm-year observations. Using this sample, we identify tax avoidance firms. We then link this information to the K10-Form data.

The second pillar of our data set is the K10-Form data. Each active owner of a CHC must file this form for each of CHC under ownership. We identify CHCs using the successful link from the corporate tax to the K10-Form data. For 259,830 firms, we have unique identifiers from the corporate tax data, which we can successfully link to the K10-Form data, thereby identifying some $61 \%$ of all Swedish corporations as closely held. In the final step, we link information from the corporate data - our tax avoidance measures - and the K10-Form data - the identification of $\mathrm{CHC}$ owners - to the representative panel of individuals.

The third and main data source is a representative panel data set of income tax returns of approximately $6.6 \%$ of the Swedish population. The raw data set contains $6,118,061$ observations and 702,077 individuals from the original representative sample. For the representative panel, we have 452,809 successful links to the K10-Form data. That is, about $2.8 \%$ of the

\footnotetext{
${ }^{11}$ See, for example, http://www.skatteverket.se/download/18.f273d1c11967381d5480001443/200217.pdf for a corporate income tax declaration for 2008 (retrieved January 18, 2013).
} 
population are active owner-managers in a $\mathrm{CHC}$. We exclude a number of observations in two steps. First, we exclude observations with missing information on age, gender, marital status, and income for at least three consecutive years. We also censor extreme observations outside the 0.01 and 99.99 percentiles of the income distribution, to remove any outliers. Second, we include only observations where the individual's age is between 18 and 70. This yields our final sample of 2,684,706 observations and 438,294 individuals.

\subsection{Variable definitions}

\subsubsection{Dependent variables}

We specify three proxies of tax avoidance as our dependent variables, based on the definitions from Section 3.2. Owing to the unique data structure, we are able to observe directly the behavior and purpose of a corporation. We then link the status of the firm to a specific individual. The dummy variable Shell Firm Owner takes the value 1 if an individual owns a CHC without economic activity, zero otherwise. The main purpose of a firm is to accumulate dividend allowances to reclassify future labor income as capital income. The dummy variable Low-Turnover Firm takes the value 1 if a taxpayer owns a CHC with some activity (for example, as a side business), zero otherwise. Together, these measures capture the incentive to run a corporation in addition to the owner's regular employment. The dummy variable Holding Corporation takes the value 1 if the $\mathrm{CHC}$ of the active owner is a holding company, zero otherwise.

As shown in Table 2, descriptive statistics indicate that about $15 \%$ of all individuals who actively participate in a CHC also actively participate in a firm regarded as a shell, low-turnover, or holding corporation. That is, more than one-seventh of Swedish owner-managers participate to at least some extent in income-shifting firms. Since the tax rules became more beneficial for income-shifting purposes with the 2006 reform, we expect an increase in the uptake of incomeshifting companies. Figure 2 depicts the percentage of CHCs designed for income-shifting purposes, according to our definitions, among newly registered CHCs.

Insert Figure 2 about here 
As expected, the percentage of holding companies, low turnover firms, and shell corporations increases in 2006 and remains at a higher level post-reform. The percentage of new firms that are shell corporations (low-turnover firms) increases to about 5\% (more than 10\%) following the reform. In 2006, we categorize more than $20 \%$ of newly founded firms as holding companies. In sum, about one-third of all newly founded CHCs in 2006 are some kind of income-shifting vehicle. This is a first indication that tax avoidance increased following the 2006 reform. Further, the 2004 increase in holding companies is very likely to be tax-related. The taxexemption for dividends and capital gains at the corporate level from unlisted shares was introduced in this year.

\subsubsection{Incentives for tax minimization}

We expect substantial cross-sectional variation in tax incentives. As long as an individual's income is below the state tax threshold, that individual is subject only to the municipality tax. In this case, the difference in the top marginal tax rates on dividends and labor income is negative. Labor income is the less-taxed income source in this case. If a taxpayer is, however, subject to the first level of the state tax of $20 \%$, the incentives change, and the difference in the top marginal tax rate is positive. Income in excess of the state tax threshold is least taxed if it is earned as capital income. We thus operationalize the tax incentive effect on tax avoidance using a simple dummy variable, State Tax $_{t-1}$, which takes the value 1 if the individual was subject to the state tax of $20 \%$ in the preceding year, zero otherwise. Table 2 presents summary statistics for our final sample. Panel A in Table 2 summarizes the income variables for the full sample. Panel B in Table 2 presents statistics on the demographic characteristics of education. As shown in Table 2, about $22 \%$ of the individual observations in our sample were subject to state tax in the preceding year. Individuals in our sample have an average taxable income over three years of SEK 236,502 (in 2006, USD 1 = SEK 7.38), of which most is labor income.

\section{Insert Table 2 about here}

The average labor income in our sample is SEK 237,408. Labor income varies considerably, from SEK 58,306 (10th percentile) to SEK 399,043 (90th percentile); that is, not every taxpayer has an incentive to establish a low-turnover firm. For example, in 2005 the threshold 
for the state tax was SEK 313,000. In 2005, about $17 \%$ of all individuals had labor income exceeding the threshold for the state tax by at least SEK 20,000 (not reported in Table 2). However, we observe that only $0.3 \%$ of the Swedish population invests in low-turnover firms $(=107,182 / 2,684,706 \times 0.0824)$. Further, we observe that capital income averages only SEK 4,409. This creates little incentive for the average taxpayer to shift income within the capital income tax base using holding corporations. Still, a considerable number of individuals have an incentive to establish a holding corporation. For example, $2.4 \%$ of taxpayers in our sample have capital income exceeding SEK 100,000, yet only $0.25 \%$ of all taxpayers are holding CHC owners. Our descriptive statistics indicate that a considerable number of individuals have tax incentives to establish tax sheltering firms; however, just a few participate in a holding, shell, or low-turnover corporation.

\subsubsection{Access to tax minimization}

One explanation for the observation that not all individuals with tax incentives participate in income shifting firms relates to access to tax avoidance. For example, the nature of the job determines whether an individual can participate in income shifting. To shift income from labor to the capital income tax base, an individual needs to cooperate with his employer. Instead of paying a wage, the employer (partly) compensates the employee through a tax sheltering firm. Since we have information on job occupation, we can analyze cross-sectional differences in access to income shifting. Specifically, we argue that consultants and accountants have the ability to cooperate with their employer. In contrast, public employees working for a central or local government have little access to such income shifting, since the employer, that is, the government, is unlikely to support it (see, for example, Kreiner, Leth-Petersen, and Skov, 2012, in the Danish context). To proxy for access through type of job occupation, we thus include dummy variables for being a consultant, accountant, or a public employee. ${ }^{12}$ The fact that one needs a third party to reclassify labor income as capital income through a low-turnover firm can also explain why the percentage of individuals responding to tax incentives is higher for

\footnotetext{
${ }^{12}$ We define a Consultant as an individual working for a management consulting company, a software or hardware consulting company, or a marketing consulting company. The job occupation Accountant covers accountants, auditors, and tax consultants. As public employees we include individuals working for a state or local government administration.
} 
holding corporations (about $10 \%=(0.25 \% / 2.4 \%)$ ) than for low-turnover corporations (about $2 \%=(0.3 \% / 17 \%))$. To establish a holding corporation and to reallocate assets to the CHC, an individual does not require a cooperating third party.

Further, to participate in income shifting under these particular tax rules, an individual must be an active owner of a CHC. However, this induces certain costs. For example, running a company is associated with accounting and reporting requirements that generally increase complexity and the costs of income-shifting mechanisms. We thus expect that there is a selfselection process associated with being an active owner. If we find evidence for such selfselection, the distribution of access to income shifting is not equal across individuals. ${ }^{13}$ We employ a two-stage estimation approach to test this expectation.

\subsubsection{Awareness of tax minimization}

Our set of demographic controls includes taxpayer age, gender, marital status, type and level of education, ${ }^{14}$ and whether the individual was born in Sweden. We use three proxies to indicate stronger awareness of the tax code and tax avoidance opportunities: namely, having higher education in either business (Business Education) or law (Law Education), and being born in Sweden (Born in Sweden). ${ }^{15}$ These three variables are expected to positively affect participation in income shifting. We additionally include age and age-squared to control for experience. We expect income shifting to be positively affected by age. However, the effect may decrease above a particular age when individuals are close to retirement. Their option value inherent in a shell corporation is much lower than for younger individuals. ${ }^{16}$

\footnotetext{
${ }^{13}$ An alternative measure of access to income shifting is ownership share. However, we use firms specifically established for tax avoidance purposes to proxy for income shifting. Therefore, there is a potential reverse causality in the ownership share. We thus do not include ownership share as a measure for access in our approach.

${ }^{14}$ We define tertiary education as a four-year university or college degree.

${ }^{15}$ Unfortunately, we have information only on whether the individual was born in Sweden. A better measure to capture awareness would be distance, e.g., geographical or cultural, of the country of birth compared to Sweden. This biases against our variable, as we treat all foreign-born individuals similarly. For example, Norwegians or Danes can more easily understand the Swedish language (and concomitantly, the Swedish tax code) than individuals from more distant countries. Further, our measure would be more accurate if we could control for year of immigration. For instance, if an individual immigrated to Sweden very early in life, that individual should face very little problem in reading and understanding the tax rules. Both these concerns qualify our findings, at least in part.

${ }^{16}$ There is, unfortunately, no information in the data on whether the tax statement was prepared by a tax consultant.
} 
After controlling for age, education, and income, country of birth is a suitably exogenous proxy for the knowledge hurdle required to understand the tax code. We expect native speakers, as proxied by birth in Sweden, to be more able to process changes in the Swedish tax codes than foreign-born individuals. As shown in Table 2, about $85 \%$ of the observations are for individuals born in Sweden. Approximately 11\% have a tertiary-level business education and about $1 \%$ have a tertiary level law education. The average taxpayer is 44.5 years of age and there are slightly more men than women in our sample (50.54\%). The business degree is the dominant type of education among individuals with higher degrees.

\section{Empirical evidence on tax avoidance}

Our empirical identification strategy has two stages. First, we assess the validity of our tax avoidance measures Shell Firm Owner, Low-Turnover Firm and Holding Corporation. If our measures of income shifting are meaningful, we should be able to observe changes in the income composition of individuals participating in these tax avoidance strategies. In particular, we are interested in the income composition of owner-managers in holding companies and low-turnover corporations. A focus on shell corporation owners is not meaningful, as income substitution can be observed at the time of income realization at the corporate level. Our definition, however, is based on expected income shifting and rules out income realization during our sample period.

If income shifting is present, we should observe it within the capital income tax base via holding companies, and from the labor to the capital income tax base via low-turnover firms. To test this prediction, we use a difference-in-difference approach around the 2006 tax reform. Second, we are interested in the individual characteristics of owners of tax avoidance firms; that is, we endogenize and model the decision to invest in a tax sheltering firm. If our tax avoidance measures detect income shifting, that is, if our difference-in-difference results are as expected, we can analyze the factors that drive the likelihood to participate in such a firm. To ensure that our difference-in-difference estimates are not biased, we use a matching procedure, described in detail below. 


\subsection{Income shifting within capital income tax base}

First, we focus on holding companies. We expect that individuals transfer shares in listed and unlisted corporations to their CHCs. In doing so, owner-managers of a holding company can postpone dividend and capital gains taxation until they decide to distribute these proceeds to the individual level. Individuals could further reduce the dividend and capital gains tax burden to $20 \%$ following the 2006 tax reform. If our simple dummy variable captures income shifting, we should be able to observe a substitution effect across income sources for owners of holding corporations around the 2006 tax reform.

We use owners of a holding $\mathrm{CHC}$ as our treatment group. We only include individuals in the treatment group if they own a holding company in all sample years (2002-2008). This condition has two advantages. First, it ensures that the decision to own a holding company is not affected by the 2006 tax reform. Second, individuals cannot enter or exit the treatment group over the sample period. The control group consists of a matched sample of CHC owners who run a $\mathrm{CHC}$ in all sample years but who do not invest in a tax sheltering company. We use a one-to-one matching procedure without replacement with respect to average income, State Tax, and demographic characteristics, as described in Table $2 .{ }^{17}$

We use five variables to measure a potential income shifting activity. First, we use total before-tax income. Second, we use total before-tax income and add the CHC's turnover to control for corporate income. Third, we use labor income to control for additional income shifting from labor to capital income. Fourth, we include the amount of CHC dividends. Finally, we are interested in dividend and interest income unrelated to any CHC. All income variables are measured before taxes. ${ }^{18}$ In the presence of income shifting, overall income is expected to remain constant relative to that of other owner-managers. However, an insignificant total income effect does not allow us to draw conclusions on the presence of income shifting. If owner-managers use their holding companies to shift assets from the individual to the corporate level, we expect that

\footnotetext{
${ }^{17}$ After matching, we detect no differences in demographic and socioeconomic characteristics between treatment and control group. The differences also do not change from before to after the reform for all variables except for one demographic characteristic (Consultant). Since we include all control variables in the regression, we are confident that our difference-in-difference estimate for the income shifting effect around the reform is not biased.

${ }^{18}$ We Winsorize income variables at the $0.1 \%$ level to prevent extreme values and outliers from biasing our results. We further exclude capital gains from capital income to account for large, one-time capital gains in the definition of permanent capital income (see, e.g., Jacob, 2012).
} 
individuals substitute capital income derived outside the $\mathrm{CHC}$ with dividends from the $\mathrm{CHC}$, for example, by shifting assets and shares in unlisted, WHCs to the holding CHC. If holding owners additionally channel some labor income through their $\mathrm{CHC}$, we should observe lower labor income post-reform. Table 3 presents the difference-in-difference estimates for the five dependent variables. We add controls (results not reported) for demographic characteristics, county-fixed effects, and year-fixed effects.

[Insert Table 3 about here]

We find that owners of holding companies do not experience higher total income growth than other CHC owners (Column 1 and 2). In fact, the difference-in-difference estimate is negative, but not significant. Most importantly, we are interested in the substitution effect of capital income related to WHCs with dividend income from CHCs. We find that holding CHC owners increase dividends from CHCs substantially relative to the control group. The difference-indifference estimate with controls is SEK 43,002 and is significant (Column 4). In contrast, the difference-in-difference estimate for capital income realized outside the CHC (Column 5) is SEK 64,849 and statistically significant. It thus appears that investors use holding companies to shift capital income from WHCs to CHCs. Further, it appears as if holding CHC owners postpone the dividend payout since the decrease in CHC-unrelated dividends is higher than the increase in $\mathrm{CHC}$ dividends. This behavior reflects income shifting across bases and over time. The negative difference-in-difference estimate for labor income indicates that these firms are also used to reclassify some labor income as dividend income. The average tax savings amount to SEK 11,105 for a holding CHC owner in the top tax bracket. ${ }^{19}$

\subsection{Income shifting from labor income to capital income}

Second, we focus on the owners of low-turnover firms. We expect that individuals actively use low turnover firms to shift income from the labor income tax base to the capital income tax base. However, these firms could also be used to generate additional income. Since the marginal

\footnotetext{
${ }^{19}$ The combined tax savings are computed as the tax advantage from shifting within the capital income tax base $($ SEK 3,242=5\% $\times 64,849)$ and from the tax wedge between labor income and capital income (SEK $7,863=((67.2 \%-42.4 \%) \times \operatorname{SEK} 31,704))$.
} 
tax rate on income earned as dividends through the $\mathrm{CHC}$ can be below the marginal income tax rate, individuals may increase labor supply and generate additional income. Also, negotiating contracts through a CHC can increase the return to labor supply as, for example, compensation per hour increases. It is an empirical question whether our definition of low-turnover firms picks up income shifting or income generation.

For this purpose, we analyze the total income and income composition of individuals who established a low-turnover firm post-reform, our treatment group. This group contains only individuals who do not participate in any CHC pre-reform. For our control group, we use a matched sample of employed individuals who do not participate in a CHC or low-turnover firm in any year. In other words, we compare employed individuals with low-turnover firms post-reform (treatment group) to employed individuals without a CHC (control group). Since the decision to establish a low-turnover firm is not exogenous (see Section 5.3), we match the individuals in our treatment group to employed individuals who are similar with respect to income, tax status, and demographic variables. By matching on these variables, we ensure that the individuals in the treatment and control groups are similar with respect to factors explaining participation in tax sheltering firms. We use a one-to-one matching procedure without replacement and ensure that taxpayers cannot move across groups. ${ }^{20}$ In the presence of income shifting, total income of individuals with a low-turnover firm is expected to be constant (relative to the control group). Capital income is expected to substitute labor income. Table 4 presents the difference-in-difference estimates using the matched sample around the 2006 reform.

\section{[Insert Table 4 about here]}

The results indicate that individuals who establish a low-turnover firm after the reform do not generate higher before-tax income than employed individuals (Column 1). Put differently, it appears that individuals with a low-turnover firm do not generate additional income. In fact, the difference-in-difference estimate is negative (SEK -23,412), but statistically insignificant. One potential explanation for this result is the lock-in of capital and profits at the corporate level. If owners of low-turnover CHCs retain a large fraction of their earnings, we may misinterpret income generation as income shifting. We thus add turnover and revenues of the

\footnotetext{
${ }^{20}$ After matching, we detect no differences in demographic and socioeconomic characteristics between treatment and control group.
} 
corporation to the owner's total income (Column 2). Still, the difference-in-difference estimate is negative (SEK -23,319) and statistically insignificant. In line with the income shifting argument, labor income of low-turnover firm owners decreases relative to the labor income of employed individuals (SEK -38,997). At the same time, the capital income of individuals in the treatment group increases post-reform by SEK 40,574. This is equivalent to tax savings of about SEK 9,671 $(=((67.2 \%-42.4 \%) \times$ SEK -38,997) $)$ for individuals in the top tax bracket.

Individuals apparently use low-turnover firms to reclassify labor income as capital income, while they do not generate additional income. This also indicates the importance of access to income shifting. Individuals with access to income shifting or individuals who establish access to income shifting firms use their CHC to shift income across tax bases to reduce overall tax liability and to increase net-of-tax income.

\subsection{Identifying characteristics of income shifters}

We next turn to OLS regression analysis, which takes advantage of the entire cross-sectional variation in the data. We are interested in the likelihood of owning a shell, low-turnover, or holding corporation. We thus endogenize the decision to own a tax sheltering firm. In our estimation approach, we must account for differences between firm owners and employed individuals. Put differently, we need to control for the potential selection bias of being an active $\mathrm{CHC}$ owner. This relates to the dimension of access to income shifting in that only the owners of CHCs can exploit the incentives inherent in the 3:12 rules. We thus run the following two-stage regression model.

$$
\begin{array}{rlr}
\text { Owner }_{i, t} & =\alpha_{1}+\delta \boldsymbol{\Gamma}_{i, t}+\gamma \cdot \text { Business } 150_{i, t-1}+\alpha_{c}+\alpha_{t}+\epsilon_{i, t} & \\
\text { Shifter }_{i, t} & =\beta_{1}+\theta \boldsymbol{\Gamma}_{i, t}+\psi \cdot \text { InvMills }_{i, t-1}+\beta_{c}+\beta_{t}+\epsilon_{i, t} & \text { if Owner } \\
i, t & =1
\end{array}
$$

In the first stage, we estimate whether an individual owns a $\mathrm{CHC}$ using a probit model (Equation 1). The dependent variable Owner is a dummy variable taking the value 1 if the individual actively participates in a $\mathrm{CHC}$, zero otherwise. The individual-level variables, denoted by the vector $\boldsymbol{\Gamma}_{i, t}$, include average income over the past two years (excluding income from 
$\mathrm{CHC}$ ), and a dummy variable if the individual was subject to the state tax in the preceding year, zero otherwise. The vector also includes demographic characteristics for being born in Sweden, age, gender, and marital status; dummy variables for tertiary education and a business, law, or information technology (IT) degree; dummy variables if the individual works as an accountant or consultant or for a central or local government agency (Public Employee); and a dummy variable if the taxpayer resides in a city. We also include age squared to control for nonlinear relations with age and being a firm-owner and income shifter, respectively. As an exogenous variable in the criterion function, we include a dummy variable Business 150 that takes the value 1 if the individual realized income of more than SEK 150,000 in the previous year from self-employment and business activity, zero otherwise. This dummy is a proxy for the incentive to incorporate an existing business to optimize the choice of organizational form. Having substantial business income and choosing the tax-optimal organizational form is not related to the type of tax avoidance that we try to capture. We also include county-fixed effects $\left(\alpha_{c}\right)$ for the 21 Swedish first-level administrative regions and year-fixed effects $\left(\alpha_{t}\right)$ to control for differences across time and counties.

In the second stage, we specify our three measures of tax avoidance activity as dependent variables. These three variables capture several dimensions of income shifting. First, we set our indicator variable Shifter to 1 if the CHC owner owns (at least) one CHC that has no economic activity. Second, we set our indicator variable Shifter to 1 if the one of the firms that the CHC owner owns is considered a low-turnover firm. Third, we set Shifter to 1 if at least one of the individual's CHCs is a holding company. We include the vector $\boldsymbol{\Gamma}_{i, t}$, the inverse Mills ratio, to control for sample selection and access to income shifting, county-fixed effects $\beta_{c}$, and year-fixed effects $\beta_{c}$ as explanatory variables. In both models, our statistical inference is based on heteroskedasticity-robust standard errors clustered at the individual level.

\section{[Insert Table 5 about here]}

Table 5 shows the regression results. The results for the criterion function (Equation 1) show that being born in Sweden, being subject to the state tax in the preceding year, marital status, holding a university degree, and having substantial business income, each increases the likelihood of being an active $\mathrm{CHC}$ owner. In contrast, the probability of being a CHC owner 
is lower if the individual is female or if the taxpayer lives in a large city. The effect of age is hump-shaped.

We are mainly interested in the individual characteristics that affect income-shifting behavior, as shown in columns (2) to (4). We find that being subject to the state tax positively affects shifting behavior. This is consistent with our expectations. Ceteris paribus, highly taxed individuals have an incentive to shift income into CHCs. The effect we find is substantial. The likelihood of being a holding firm owner increases by over 10.4 percentage points (over 160\% of the unconditional mean) if the individual is subject to the state tax. Likewise, the likelihood of being a shell corporation owner increases by 1.1 percentage points (or $67 \%$ of the unconditional mean). Yet there is some concern that this dummy variable is correlated with other variables. For example, it could capture an income effect (high versus low income) instead of a tax effect. We address this concern in Section 5.4 below using local linear regressions around the major kink in the marginal tax rate schedule.

We are next interested in the factors related to awareness of income shifting. We designate the variables Age, Born in Sweden, Tertiary Education, and the types of education as our main variables of interest. Our results suggest that having a degree in business or economics significantly increases the likelihood of participating in income shifting. However, we cannot interpret our results as indicating a causal link between education and income shifting, because our measures capture many dimensions related to awareness. For example, an individual with a business degree may not only have greater knowledge about tax rules through education, but also stronger individual preferences for business matters, at least compared with graduates in other disciplines. We also find some evidence that individuals born in Sweden are more likely to participate in income shifting. After controlling for education and income, country of birth is a good proxy for hurdles in understanding the tax code. From this, we cautiously conclude that awareness of the tax rules appears to be one economically significant factor explaining part of the heterogeneity in participation in income shifting across individuals.

In addition, we find a significant effect of age in the form of an inverted U-shaped function. For low turnover firms, only age squared is significant. These results indicate that experience measured via age is one determinant of participation in income shifting. We observe consistent 
effects for the variable Female. Once again, the effects are economically substantial in that the likelihood of owning a holding company increases by 7.1 percentage points (over $100 \%$ of the unconditional mean) if the individual is male.

Finally, we are interested in the variables related to access. Our controls for job occupation indicate that individuals with easier access to income shifting are more likely to own a tax sheltering firm. For example, the likelihood of owning a shell corporation increases by $51 \%$ if the individual is a consultant. At the same time, public employees are less likely to shift income across tax bases, due to lack of access - since the employer, that is, the government, is unlikely to cooperate in income shifting. Not surprisingly, being an accountant has a strong effect on the likelihood of owning a tax sheltering firm. The likelihood of owning a shell corporation increases by $132 \%$ if the individual is an accountant, that is, an individual with both awareness and access.

The significance of the inverse Mills ratio indicates the importance of controlling for both sample selection and access to income-shifting opportunities. Self-selection indicates that distribution of access to income shifting is not equal across individuals. The result of the Business Degree coefficient is further related to access to tax avoidance. Taken together, the results of Kleven, Knudsen, Kreiner, Pedersen, and Saez (2011) and our results indicate that highly educated individuals participate less in illegal tax evasion and more in legal tax avoidance. Access to tax evasion through underreporting of income is limited for individuals with higher education due to the nature of their professions. A self-employed individual providing manual labor to private clients can more easily arrange for "under-the-table" payments than highly educated individuals such as business consultants. The latter sell services to clients that expect receipts to deduct these costs from their taxable income. This effectively limits access to illegal tax evasion. Tax minimization thus necessitates access to legal tax avoidance, for example, through any of the types of income shifting firms described above.

\subsection{Tax incentive and local linear regressions}

Let us turn to a more detailed analysis of the tax incentive to address concerns about our tax incentive measure. First, our definition could capture an income effect (high versus low income) 
instead of a tax effect. Even if we include the marginal tax rate as an explanatory variable, concerns about the correlation between income and the marginal tax rate remain. Second, the regression analysis above captures a correlation. However, we are particularly interested in a causal link between taxes and income shifting.

The marginal tax rate structure of the Swedish tax code provides a good opportunity to test the tax effect on income-shifting activities. We use the kink of 20 percentage points in the marginal tax rate function around the first state tax threshold and employ a local linear regression. If tax incentives drive legal tax avoidance, individuals slightly above the state tax threshold should be more likely to participate in income shifting than individuals below the threshold. We believe that a tax rate increase of 20 percentage points is sufficiently large to identify this change in behavior. Further, this tax rate increase is very salient (see Chetty, Looney, and Kroft, 2009; Finkelstein, 2009, on tax salience)). Below the threshold, individuals pay only municipality income tax. Above this threshold, their income is subject to an additional $20 \%$ state tax, as explicitly stated in the tax assessment. As these different levels of tax rates have different names, the kink very salient to taxpayers. We use ranges of SEK 5,000, SEK 10,000, and SEK 20,000 (about USD 678, USD 1,355, and USD 2,710 in 2006) around the state tax threshold.

We use a local linear regression design, with our income shifting measures as the dependent variable and the State Tax Threshold dummy as the explanatory variable of interest. Again, we define the dummy variable for the tax incentive based on the prior year. There are two concerns about using a local linear regression around the tax threshold. The first relates to bunching at kink points (Saez, 2010). For example, Bastani and Selin (2012) show bunching of the selfemployed around the major kink point in Sweden. We, however, believe that bunching does not bias our estimate of the tax incentive on income shifting upwards. If individuals who bunch and show awareness of tax incentives are normally distributed around the kink, crossing the state tax threshold does not change the tax incentives to participate in income shifting firms for these individuals. There are reasons to believe that bunching could drive our coefficient towards zero. First, not all individuals bunch at kink points. Second, it is reasonable to assume that the presence of bunching rather leads to more individuals locating below the state tax threshold. 
In fact, $52 \%$ to $54 \%$ of taxpayers are below the threshold for our three ranges of SEK 5,000 to 20,000. This gives us confidence that our estimates are not biased upwards due to bunching. A second concern about the local linear regression is that individuals are similar across groups. The local linear regression design can be applied only if individual characteristics around the state tax threshold are similar.

\section{[Insert Table 6 about here]}

Table 6 presents differences between individuals above and below the threshold. The data around the threshold appears to be reasonably smooth, and we are therefore confident that we are able to identify a tax effect. With one exception, all differences are statistically insignificant. We nevertheless test the robustness of our results by controlling for demographic characteristics, selection, and county-fixed effects as well as year-fixed effects. We present the results for the three income ranges around the state tax threshold and for our three income shifting measures.

\section{[Insert Table 7 about here]}

Our results in Table 7 show that crossing the state tax threshold increases the likelihood of participating in income shifting. We consistently find a statistically and economically significant effect of crossing the state tax threshold on tax avoidance activities with and without controls. This effect is surprising, since the incentive to participate in a holding company is actually independent from the marginal income tax on labor income. Yet, the visibility of the kink in the tax code raises awareness of incentives to reduce taxes. Further, our analysis in Section 5.1 shows that holding firms also facilitate some income shifting from labor income to capital income.

The effects of crossing the state tax threshold on participation in income shifting for shell corporations and holding companies are economically significant. For example, crossing the state tax threshold (using the SEK 5,000 range around the threshold) increases the likelihood of owning a holding company by 1.6 percentage points or about $100 \%$ of the unconditional mean. One potential explanation for this strong effect is the salience of the increase in marginal income tax. Once individuals cross the state tax threshold, they become aware of their change in the marginal tax rate and they respond to tax incentives. At first glance, it may still appear 
irrational to establish a shell corporation or a low-turnover corporation just because one has crossed the state tax threshold by a small amount. The tax savings on this small amount of income in excess of the state tax threshold does not cover the costs of a CHC. However, the option value inherent in the possibility to carry forward and accumulate dividend allowances with interest and expected income growth provide rational explanations for why individuals participate in these income shifting firms.

We also test two further kinks in the tax code that are less tax salient. First, social security contributions cease to create benefit above a particular income level. Second, there is a second stage of the state tax of an additional 5\%. Both thresholds are well above the first state tax threshold. In contrast to the first state tax threshold, these two kinks in the marginal tax rate do not create an incentive to establish a low-turnover or a shell corporation. Both kinks simply increase the benefits of income shifting using shell corporations and low-turnover corporations. We find no significant effect from crossing these two thresholds on the likelihood to participate in income shifting, using local linear regression around the respective thresholds. From this, we conclude that tax incentives and their salience are key sources of the heterogeneity in income shifting across individuals.

\subsection{Awareness and Network Effects}

Our final concern relates to the measure of awareness. Our proxies of awareness include age, level of education, type of education, and country of birth. However, these variables may be correlated with other variables, such as income and may thus be poor proxies for the effect of awareness on income shifting. We thus use a more exogenous measure based on network theory (see, Alstadsæter, Kopczuk, and Telle, 2012). Policy makers interpreted the 2006 reform as a minor adjustment to the tax code with very little awareness that incentives to participate in income shifting had changed. However, anecdotal evidence suggests that tax consultants understood these changes in incentives and helped individuals to establish income shifting firms.

We use cross-municipality differences in the density of tax avoidance as a measure of tax awareness. We define each municipality - the 290 lower-level local government entities - as a 
network. If more individuals in a municipality participate in an income shifting firm, information spreads more easily within the network and individuals are more likely to participate in income shifting as well.

We test this effect using logit regressions on the likelihood to establish an income shifting firm. Our dependent variable is a dummy variable equal to 1 if the individual establishes an income shifting firm in year $\mathrm{t}$ and if the individual has not actively participated in a $\mathrm{CHC}$ in the prior year $t$-1, zero otherwise. As our key explanatory variable, we use the percentage of shell, low-turnover, or holding corporation owners in the municipality in the previous year. The percentage is based on the whole population. Alternatively, we use the percentage of individuals in a municipality that participate in any of these three firm types in year $t$ - 1 . If the network theory using our very broad definition of a municipality as a network holds, we should obtain a positive coefficient on the percentage of income shifters in a network.

[Insert Table 8 about here]

Table 8 shows regression results from logit regressions using the full sample of individuals. We find that the network effect is positive and significant in all specifications and for all measures of income shifting. This indicates that part of the cross-sectional variation in participation in income shifting can be explained by awareness. If information spreads through networks, e.g., through a higher density of tax consultants in a municipality, the likelihood of participating in income shifting in a network increases. This makes us confident that awareness of tax incentives is an important explanation for why some individuals participate in income shifting and others do not.

\section{Conclusion}

We document substantial heterogeneity with respect to access, incentive, and awareness in participation in income shifting across individuals. All three conditions are required for taxpayers to actively avoid taxes. Our results point towards differences in the effect of socioeconomic variables on illegal tax evasion and on legal tax avoidance. In contrast to participation in illegal tax evasion (Kleven, Knudsen, Kreiner, Pedersen, and Saez, 2011), we find a strong and 
positive effect of tax rates on participation in legal tax avoidance. Further, tertiary business education and age have positive effects on participation in legal tax avoidance. Gender is one of the few factors that points in the same direction for tax evasion as for tax avoidance: Women are less likely to participate in any form of tax minimization.

Our results have important policy implications for tax authorities. In the presence of heterogeneity in the take-up of tax incentives, unintended consequences of tax reforms can occur. For example, if taxpayers are not informed about tax incentives or if tax incentives are complex, costly to pursue, and/or not transparent, only some taxpayers respond to tax incentives. Complex and non-transparent reforms that are poorly communicated are likely to promote income shifting and tax avoidance strategies. This has unintended consequences on horizontal and vertical equity, as informed, highly-taxed and educated individuals are more likely to respond to tax incentives. Studying the welfare consequences of heterogeneity in legal tax avoidance is a natural avenue for further investigation. 


\section{References}

Alstadsæter, Annette and Martin Jacob (2012): Income Shifting in Sweden - An empirical evaluation of the 3:12 rules. Report to the Expert Group for Public Economics, Ministry of Finance, Stockholm.

Alstadsæter, Annette, Wojciech Kopczuk, and Kjetil Telle (2012): Social networks and individuals' tax avoidance participation, Mimeo, University of Oslo, Columbia University, and Statistics Norway.

Andreoni, James, Brian Erard, and Jonathan Feinstein (1998): Tax compliance, Journal of Economic Literature, 36: 818-860.

Bastani, Spencer and Håkan Selin (2012): Bunching and Non-Bunching at Kink Points of the Swedish Tax Schedule, Cesifo Working Paper No. 3865.

Chetty, Raj, Adam Looney, and Kory Kroft (2009): Salience and Taxation: Theory and Evidence, American Economic Review, 99: 1145-1177.

Chetty, Raj and Emmanuel Saez (2005): Dividend taxes and corporate behavior. Evidence from the 2003 dividend tax cut, Quarterly Journal of Economics, 120: 791-833.

Dyreng, Scott, Michelle Hanlon, and Edward L. Maydew (2010): The Effects of Executives on Corporate Tax Avoidance, The Accounting Review, 85: 1163-1189.

Elschner, Christina (2013): Special tax regimes and the choice of organizational form: Evidence from the European Tonnage Taxes, Journal of Public Economics, 97: 206-216.

Finkelstein, Amy (2009): E-ZTAX: Tax Salience and Tax Rates, Quarterly Journal of Economics, 124: 969-1010.

Fortin, Bernard, Guy Lacroix, and Marie-Claire Villeval (2007): Tax evasion and social interactions, Journal of Public Economics, 91: 2089-2112.

Goolsbee, Austan (2000): What Happens When You Tax the Rich? Evidence from Executive Compensation, Journal of Political Economy, 108: 352-378.

Gordon, Roger. H. and Jeffrey K. Mackie-Mason (1994): Tax Distortions to the Choice of Organizational Form, Journal of Public Economics, 55: 279-306.

Ivković, Zoran, James M. Poterba, and Scott J. Weisbenner (2005): Tax-Motivated Trading by Individual Investors, American Economic Review, 95 (5): 1605-1630.

Jacob, Marcus and Martin Jacob (2012): Taxation, Dividends, and Share Repurchases: Taking Evidence Global, Journal of Financial and Quantitative Analysis, forthcoming. 
Jacob, Martin (2012): Tax Regimes and Capital Gains Realizations, FAccT Center Working Paper No. 06/2012.

Jones, Damon (2012): Inertia and Overwithholding: Explaining the Prevalence of Income Tax Refunds, American Economic Journal: Economic Policy, 4: 158-185.

Kleven, Henrik, Martin Knudsen, Claus Thustrup Kreiner, Soren Pedersen, and Emmanuel Saez (2011): Unwilling or Unable to Cheat? Evidence from a Tax Audit Experiment in Denmark, Econometrica, 79: 651-692.

Kopczuk, Wojciech (2007): Bequest and Tax Planning: Evidence from Estate Tax Returns, Quarterly Journal of Economics, 122: 1801-1854.

Kopczuk, Wojciech (2012): The Polish business "flat" tax and its effect on reported incomes: a Pareto improving tax reform?, Mimeo, Columbia University.

Kopczuk, Wojciech and Joel B. Slemrod (2006): Putting Firms into Optimal Tax Theory, American Economic Review, 96: 130-134.

Kreiner, Claus Thustrup, Søren Leth-Petersen, and Peer Ebbesen Skov (2012): Tax Reforms and Intertemporal Shifting of Wage Income: Evidence from Danish Monthly Payroll Records, Working Paper.

Pirttilä, Jukka and Håkan Selin (2011): Income Shifting Within a Dual Income Tax System. Evidence from the Finnish Tax Reform of 1993, Scandinavian Journal of Economics, 113: $120-144$.

Romanov, Dmitri (2006): The Corporation as a Tax Shelter: Evidence from Recent Israeli Tax Changes, Journal of Public Economics, 90: 1939-1954.

Saez, Emmanuel (2010): Do Taxpayers Bunch at Kink Points?, American Economic Journal: Economic Policy, 2: 180-212.

Saez, Emmanuel, Joel B. Slemrod, and Seth H. Giertz (2012): The elasticity of taxable income with respect to marginal tax rates: A critical review, Journal of Economic Literature, 50: $3-50$.

Shaw, Jonathan, Joel B. Slemrod, and John Whiting (2010): Administration and Compliance, In Dimensions of Tax Design. The Mirrlees Review. Oxford University Press, pages 11001162.

Slemrod, Joel B., Marsha Blumenthal, and Charles W. Christian (2001): Taxpayer response to an increased probability of audit: evidence from a controlled experiment in Minnesota, Journal of Public Economics, 79: 455-483. 
Slemrod, Joel B. and Shlomo Yitzhaki (2002): Tax avoidance, evasion, and administration, In Alan J. Auerbach and Martin Feldstein, editors, Handbook of Public Economics, volume 3, page 1423-1470. Elsevier.

Stephens, Melvin Jr. and Jennifer Ward-Batts (2004): The impact of separate taxation on the intra-household allocation of assets: evidence from the UK, Journal of Public Economics, 88: 1989-2007.

Stiglitz, Joseph E. (1985): The General Theory of Tax Avoidance, National Tax Journal, 38: $325-338$.

Thoresen, Thor O. and Annette Alstadsæter (2010): Shifts in Organizational Form under a Dual Income Tax System, FinanzArchiv/Public Finance Analysis, 66: 384-418. 
Figure 1: Matching of Corporate and Income Tax Information via K10-forms

\begin{tabular}{|c|c|c|}
\hline $\begin{array}{l}\text { Corporate } \\
\text { Tax Panel }\end{array}$ & "K10" Form & $\begin{array}{c}\text { Income Tax } \\
\text { Panel }\end{array}$ \\
\hline Firm ID & $\begin{array}{l}\text { Firm-Individual ID } \\
\text { Combinations }\end{array}$ & Indiviudal ID \\
\hline $\begin{array}{l}\text { - Information on } \\
426,712 \text { firms who } \\
\text { file corporate tax } \\
\text { return (INK2) }\end{array}$ & $\begin{array}{l}\text { - Information on all } \\
\text { owners who file K10 } \\
\text { forms for their closely } \\
\text { held firms }\end{array}$ & $\begin{array}{l}\text { - Information on } \\
702,077 \text { individuals } \\
\text { who file income tax } \\
\text { statement (INK 1) }\end{array}$ \\
\hline
\end{tabular}

Figure 2: Shell, Low-Turnover, and Holdings Corporations, 2001-2008

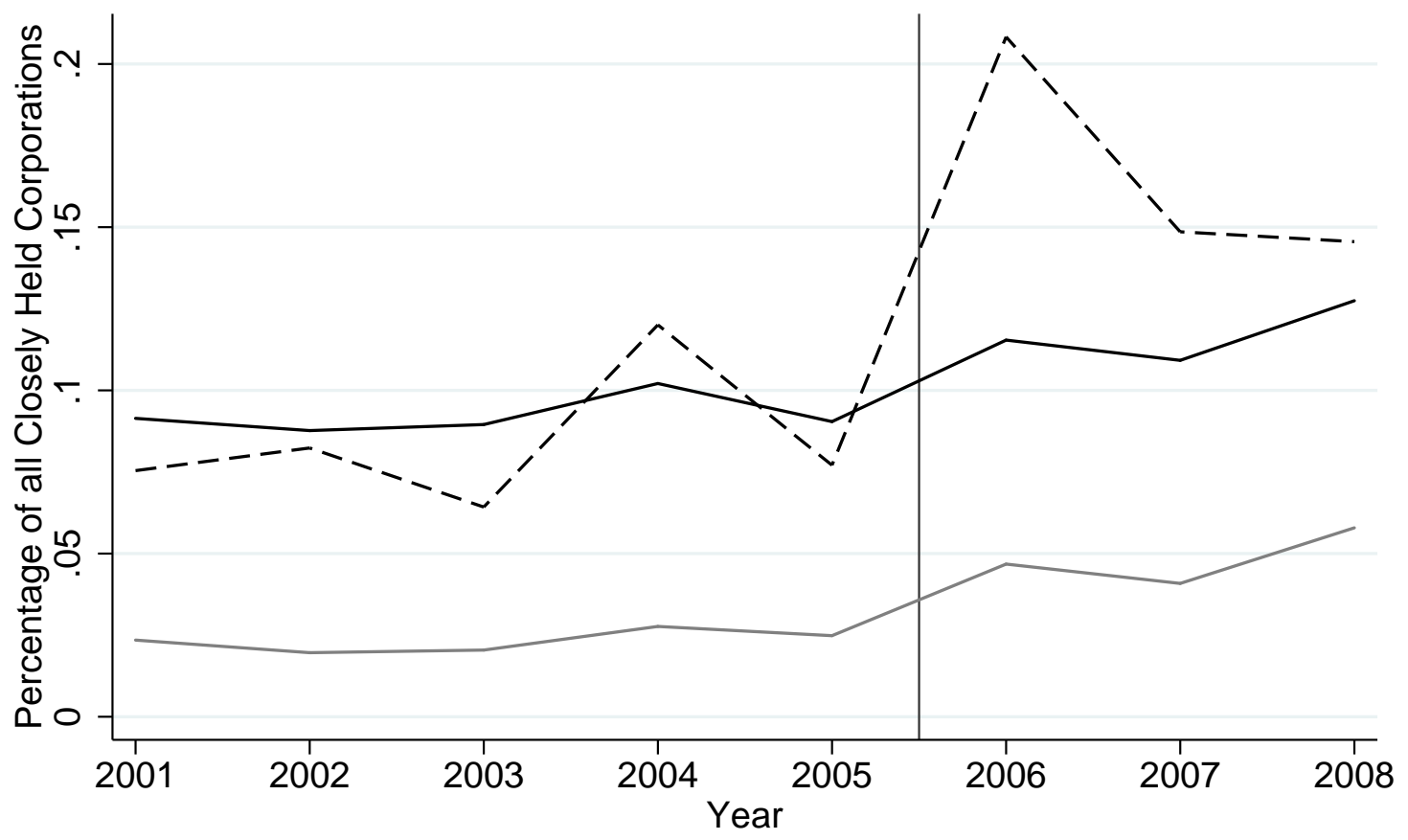

\footnotetext{
New Low Turnover Firms

New Holding Corporations

New Shell Corporations
} 
Table 1: Marginal tax rates and thresholds in Sweden, 2000-2008

\begin{tabular}{|c|c|c|c|c|c|c|c|c|c|}
\hline \multirow[t]{2}{*}{ Year } & \multicolumn{6}{|c|}{ Labor income } & \multicolumn{3}{|c|}{ Capital income } \\
\hline & $\begin{array}{c}\text { Munici- } \\
\text { pality } \\
\text { tax }\end{array}$ & $\begin{array}{l}\text { State } \\
\text { tax1 }\end{array}$ & $\begin{array}{l}\text { Threshold } \\
\text { for state } \\
\text { tax } 1\end{array}$ & $\begin{array}{l}\text { State } \\
\operatorname{tax} 2\end{array}$ & $\begin{array}{l}\text { Threshold } \\
\text { for state } \\
\text { tax } 2\end{array}$ & $\begin{array}{c}\text { Social } \\
\text { security }^{a}\end{array}$ & $\begin{array}{c}\text { Corp. } \\
\text { Tax }\end{array}$ & $\begin{array}{c}\text { Dividend } \\
\mathrm{WHC}^{b}\end{array}$ & $\begin{array}{c}\text { Dividend } \\
\mathrm{CHC}^{c}\end{array}$ \\
\hline 2000 & $30.40 \%$ & $20 \%$ & 254,600 & $5 \%$ & 398,500 & $32.90 \%$ & $28 \%$ & $30 \%$ & $30 \%$ \\
\hline 2001 & $30.50 \%$ & $20 \%$ & 271,500 & $5 \%$ & 411,100 & 32.80 & $28 \%$ & $30 \%$ & $30 \%$ \\
\hline 2002 & $30.50 \%$ & $20 \%$ & 290,100 & $5 \%$ & 430,900 & $32.80 \%$ & $28 \%$ & $30 \%$ & $30 \%$ \\
\hline 2003 & $31.20 \%$ & $20 \%$ & 301,000 & $5 \%$ & 447,200 & $32.80 \%$ & $28 \%$ & $30 \%$ & $30 \%$ \\
\hline 2004 & $31.50 \%$ & $20 \%$ & 308,800 & $5 \%$ & 458,900 & $32.70 \%$ & $28 \%$ & $30 \%$ & $30 \%$ \\
\hline 2005 & $31.60 \%$ & $20 \%$ & 313,000 & $5 \%$ & 465,200 & $32.50 \%$ & $28 \%$ & $30 \%$ & $30 \%$ \\
\hline 2006 & $31.60 \%$ & $20 \%$ & 317,700 & $5 \%$ & 472,300 & $32.30 \%$ & $28 \%$ & $25 \% / 30 \%$ & $20 \%$ \\
\hline 2007 & $31.60 \%$ & $20 \%$ & 328,600 & $5 \%$ & 488,600 & $32.40 \%$ & $28 \%$ & $25 \% / 30 \%$ & $20 \%$ \\
\hline 2008 & $31.40 \%$ & $20 \%$ & 340,900 & $5 \%$ & 507,100 & $32.40 \%$ & $28 \%$ & $25 \% / 30 \%$ & $20 \%$ \\
\hline \multicolumn{10}{|c|}{$\begin{array}{l}\text { The thresholds for the first and second level of state tax are defined in Swedish Krona (SEK). In } 2006 \text {, } \\
\text { USD } 1 \text { equals SEK } 7.38 \text {. } \\
a \text { Social security contributions are remitted by the employer at the corporate level. } \\
b \text { As of } 2006 \text {, dividends from unlisted, widely held firms are taxed at } 25 \% \text {. Dividends from listed firms } \\
\text { are taxed at } 30 \% \text {. } \\
{ }^{c} \text { Dividends exceeding the dividend allowance are taxed as labor income in all years. Until 2005, there } \\
\text { was a small proportion of dividends that was tax exempt. This was equal to } 0.7 \text { times the interest rate } \\
\text { on government bonds times nominal equity. }\end{array}$} \\
\hline
\end{tabular}




\section{Table 2: Summary Statistics}

This table presents descriptive statistics of our main variables for the representative panel of individuals over the 20022008 sample period. Average Income I $_{-2, t}$ is the average income over three periods, excluding income from the closely held corporation (CHC). State Tax is a dummy variable equal to 1 if earned income (labor and business income) in the preceding year exceeds the threshold for the state tax of $20 \%$. Labor Income (Business Income) compromises all wages and salaries (income from self-employment). Capital Income includes dividends, capital gains, and interest. Dividends (Dividends $\mathrm{CHC}$ ) is the sum of all dividends (dividends from CHCs). Business 150 is a dummy variable equal to 1 if income from self-employment (business income) in the preceding year exceeds SEK 150,000. Born in Sweden is an indicator variable equal to 1 if the taxpayer was born in Sweden. Age is the taxpayer's age in years. Female is a dummy variable equal to 1 if the taxpayer is female, zero otherwise. Married is a dummy variable equal to 1 if the taxpayer is married. Consultant is a dummy variable equal to 1 if the individual works as a consultant in the IT, business, or marketing sector. Accountant is a dummy variable equal to 1 if the individual works in an accounting, book-keeping, or tax consulting firm. Tertiary Education is a dummy variable equal to 1 if the individual holds a tertiary education degree of at least four years of college or university education. Public Employee is a dummy variable if the individual works in the public administration of central or local governments. Business Degree is a dummy variable equal to 1 if the taxpayer holds a tertiary degree in business administration or economics. Law Education (IT Education) is a dummy variable equal to 1 if the individual has studied law (computer sciences). City is an indicator variable equal to 1 if the individual resides in a city with a population of more than 10,000 persons. Shell Firm Owner is a dummy variable equal to 1 if the taxpayer actively participates in a CHC that is a shell corporation with no turnover. Low-Turnover Firm is a dummy variable equal to 1 if the individual actively participates in a $\mathrm{CHC}$ that is a low-turnover firm. Holding Corporation is a dummy variable equal to 1 if the individual actively participates in a CHC that is a holding firm.

\begin{tabular}{|c|c|c|c|c|c|c|}
\hline Variable & $\mathrm{N}$ & Mean & $\begin{array}{l}\text { Standard } \\
\text { Deviation }\end{array}$ & $\begin{array}{c}\text { 10th } \\
\text { Percentile }\end{array}$ & Median & $\begin{array}{c}90 \text { th } \\
\text { Percentile }\end{array}$ \\
\hline
\end{tabular}

Panel A: Income Elements

\begin{tabular}{|c|c|c|c|c|c|c|}
\hline Average Income $_{t-2, t}$ & $2,684,706$ & 236,502 & 230,066 & 61,473 & 212,599 & 401,132 \\
\hline State Tax & $2,684,706$ & 0.2246 & 0.4173 & 0.0000 & 0.0000 & 1.0000 \\
\hline Labor Income & $2,684,706$ & 237,408 & 168,757 & 58,306 & 222,800 & 399,043 \\
\hline Business Income & $2,684,706$ & 6,347 & 41,756 & 0.0000 & 0.0000 & 0.0000 \\
\hline Capital Income & $2,684,706$ & 4,409 & 89,960 & $-19,361$ & 0 & 10,311 \\
\hline Dividends & $2,684,706$ & 3,790 & 49,236 & 0 & 5 & 3,753 \\
\hline Business 150 & $2,684,706$ & 0.0169 & 0.1288 & 0.0000 & 0.0000 & 0.0000 \\
\hline \multicolumn{7}{|c|}{ Panel B: Demographic Characteristics } \\
\hline Born in Sweden & $2,684,706$ & 0.8540 & 0.3531 & 0.0000 & 1.0000 & 1.0000 \\
\hline Age & $2,684,706$ & 44.5300 & 14.0600 & 25.0000 & 44.0000 & 64.0000 \\
\hline Female & $2,684,706$ & 0.4946 & 0.5000 & 0.0000 & 0.0000 & 1.0000 \\
\hline Married & $2,684,706$ & 0.4332 & 0.4955 & 0.0000 & 0.0000 & 1.0000 \\
\hline Consultant & $2,684,706$ & 0.0245 & 0.1547 & 0.0000 & 0.0000 & 0.0000 \\
\hline Accountant & $2,684,706$ & 0.0042 & 0.0647 & 0.0000 & 0.0000 & 0.0000 \\
\hline Public Employee & $2,684,706$ & 0.0120 & 0.1089 & 0.0000 & 0.0000 & 0.0000 \\
\hline Tertiary Education & $2,684,706$ & 0.1479 & 0.3550 & 0.0000 & 0.0000 & 1.0000 \\
\hline Business Degree & $2,684,706$ & 0.1073 & 0.3095 & 0.0000 & 0.0000 & 1.0000 \\
\hline Law Education & $2,684,706$ & 0.0080 & 0.0892 & 0.0000 & 0.0000 & 0.0000 \\
\hline IT Education & $2,684,706$ & 0.0113 & 0.1057 & 0.0000 & 0.0000 & 0.0000 \\
\hline City & $2,684,706$ & 0.7371 & 0.4402 & 0.0000 & 1.0000 & 1.0000 \\
\hline \multicolumn{7}{|c|}{ Panel C: Statistics on Closely Held Corporation Owners } \\
\hline Shell Firm Owner & 107,182 & 0.0164 & 0.1269 & 0.0000 & 0.0000 & 0.0000 \\
\hline Low Turnover CHC & 107,182 & 0.0824 & 0.2750 & 0.0000 & 0.0000 & 0.0000 \\
\hline Holding Corporation & 107,182 & 0.0633 & 0.2434 & 0.0000 & 0.0000 & 0.0000 \\
\hline Dividends CHC & 107,182 & 29,511 & 147,543 & 0 & 0 & 59,333 \\
\hline
\end{tabular}




\section{Table 3: Substitution versus Income Generation: Holding Firms}

This table presents difference-in-difference estimates estimated over the period 2002-2008. Our treatment group consists of individuals with a holding $\mathrm{CHC}$ in all sample years. As a control group, we use use a matched sample of closely held corporation (CHC) owners that do not participate in any income shifting firm over the sample period. We use a one-to-one matching procedure without replacement with respect to average income, State Tax, and demographic characteristics (see Table 2 for an overview and description of all variables). We present differencein-difference estimates for total before tax income (Column 1), overall before tax income which includes the CHC's turnover (Column 2), labor income (Column 3), dividends from the CHC (Column 4), and capital income (without capital gains) unrelated to the CHC (Column 5). We include demographic control variables (see Panel B of Table 2 ), county-fixed effects, and year-fixed effects. Standard errors (shown in parentheses) allow for heteroskedasticity clustered at the individual level. $* * *, * *$, and $*$ denote significance at the $1 \%, 5 \%$, and $10 \%$ levels, respectively.

$\begin{array}{ccccc}\text { Total Income } & \text { Total Income } & \text { Labor } & \text { Dividends } & \text { Capital } \\ \text { w/o Turnover } & \text { with Turnover } & \text { Income } & \text { from CHC } & \text { Income }\end{array}$

$(1)$

\begin{tabular}{lccccc}
\hline Diff-in-Diff & $-23,412$ & $-23,319$ & $-31,704^{* *}$ & $43,002^{* *}$ & $-64,849^{* *}$ \\
Estimate & $(33,912)$ & $(33,944)$ & $(14,301)$ & $(20,597)$ & $(31,189)$ \\
\hline Controls & Yes & Yes & Yes & Yes & Yes \\
Year-FE & Yes & Yes & Yes & Yes & Yes \\
County-FE & Yes & Yes & Yes & Yes & Yes \\
Observations & 8,291 & 8,291 & 8,291 & 8,291 & 8,291 \\
\hline
\end{tabular}

\section{Table 4: Substitution versus Income Generation: Low-Turnover Firms}

This table presents difference-in-difference estimates estimated over the period 2002-2008. Our treatment group consists of low-turnover firm owners that actively participate in a low-turnover firm after 2006 . These are individuals employed before the tax reform of 2006. As a control group, we use a matched sample of employed individuals that do not participate in a closely held corporation (CHC). We use a one-toone matching procedure without replacement with respect to average income, State Tax, and demographic characteristics (see Table 2 for an overview and description of all variables). We present difference-indifference estimates for total income without and with the turnover of the low turnover firm, labor income, and capital income (without capital gains and losses). Standard errors (shown in parentheses) allow for heteroskedasticity clustered at the individual level. $* * *, * *$, and $*$ denote significance at the $1 \%, 5 \%$, and $10 \%$ levels, respectively.

\begin{tabular}{lcccc}
\hline & $\begin{array}{c}\text { Total Income } \\
\text { w/o Turnover }\end{array}$ & $\begin{array}{c}\text { Total Income } \\
\text { with Turnover }\end{array}$ & $\begin{array}{c}\text { Labor } \\
\text { Income }\end{array}$ & $\begin{array}{c}\text { Capital } \\
\text { Income }\end{array}$ \\
\hline Diff-in-Diff & $-20,343$ & $-8,800$ & $-38,997^{* *}$ & $40,574^{* * *}$ \\
Estimate & $(23,192)$ & $(2,235)$ & $(16,203)$ & $(19,914)$ \\
\hline Controls & Yes & Yes & Yes & Yes \\
Year-FE & Yes & Yes & Yes & Yes \\
County-FE & Yes & Yes & Yes & Yes \\
Observations & 4,353 & 4,353 & 4,353 & 4,353 \\
\hline
\end{tabular}


Table 5: Individual Characteristics and Tax Avoidance Strategies

This table presents the results for income-shifting behavior from a two-stage regression estimated over the period 20022008. The first column reports results from the selection model using CHC ownership (dummy variable) as the dependent variable. Columns (2) to (4) present coefficient estimates using different dimensions of income shifting as dependent variables. All dependent and independent variables are as described in Table 2. Standard errors (shown in parentheses) allow for heteroskedasticity clustered at the individual level. ***, **, and * denote significance at the $1 \%, 5 \%$, and $10 \%$ levels, respectively.

\begin{tabular}{|c|c|c|c|}
\hline First Stage & Second Stą & : Dimensions c & ax Avoidance \\
\hline $\begin{array}{c}\text { Firm } \\
\text { Ownership }\end{array}$ & $\begin{array}{c}\text { Shell } \\
\text { Corporation }\end{array}$ & $\begin{array}{c}\text { Low-Turnover } \\
\text { Corporation }\end{array}$ & $\begin{array}{c}\text { Holding } \\
\text { Corporation }\end{array}$ \\
\hline
\end{tabular}

\begin{tabular}{|c|c|c|c|c|}
\hline Constant & $\begin{array}{c}-4.4810^{* * *} \\
(0.0468)\end{array}$ & $\begin{array}{c}-0.1021^{* * *} \\
(0.0289)\end{array}$ & $\begin{array}{c}-0.0536 \\
(0.0893)\end{array}$ & $\begin{array}{c}-0.7115^{* * *} \\
(0.0767)\end{array}$ \\
\hline Average Income $_{t-2, t}$ & $\begin{array}{c}-0.0881^{* * *} \\
(0.0039)\end{array}$ & $\begin{array}{c}0.0001 \\
(0.0002)\end{array}$ & $\begin{array}{c}0.0016 \\
(0.0012)\end{array}$ & $\begin{array}{c}0.0000 \\
(0.0007)\end{array}$ \\
\hline State Tax & $\begin{array}{c}0.5053^{* * *} \\
(0.0094)\end{array}$ & $\begin{array}{c}0.0110^{* * *} \\
(0.0025)\end{array}$ & $\begin{array}{c}0.0177^{* *} \\
(0.0082)\end{array}$ & $\begin{array}{c}0.1042^{* * *} \\
(0.0067)\end{array}$ \\
\hline Born in Sweden & $\begin{array}{c}0.3826^{* * *} \\
(0.0117)\end{array}$ & $\begin{array}{c}0.0010 \\
(0.0040)\end{array}$ & $\begin{array}{c}0.0314^{* * *} \\
(0.0086)\end{array}$ & $\begin{array}{c}0.0627^{* * *} \\
(0.0073)\end{array}$ \\
\hline Age & $\begin{array}{c}0.1089^{* * *} \\
(0.0021)\end{array}$ & $\begin{array}{c}0.0021^{* * *} \\
(0.0008)\end{array}$ & $\begin{array}{c}-0.0038^{*} \\
(0.0022)\end{array}$ & $\begin{array}{c}0.0147^{* * *} \\
(0.0018)\end{array}$ \\
\hline Age2/1000 & $\begin{array}{c}-1.1034^{* * *} \\
(0.0222)\end{array}$ & $\begin{array}{c}-0.0200^{* *} \\
(0.0079)\end{array}$ & $\begin{array}{c}0.0559^{* *} \\
(0.0225)\end{array}$ & $\begin{array}{c}-0.1491 * * * \\
(0.0186)\end{array}$ \\
\hline Female & $\begin{array}{c}-0.4737^{* * *} \\
(0.0075)\end{array}$ & $\begin{array}{c}-0.0146^{* * *} \\
(0.0029)\end{array}$ & $\begin{array}{c}-0.0273^{* * *} \\
(0.0086)\end{array}$ & $\begin{array}{c}-0.0709^{* * *} \\
(0.0074)\end{array}$ \\
\hline Marital Status & $\begin{array}{c}0.2560^{* * *} \\
(0.0069)\end{array}$ & $\begin{array}{c}0.0020 \\
(0.0022)\end{array}$ & $\begin{array}{c}0.0098^{*} \\
(0.0054)\end{array}$ & $\begin{array}{c}0.0366^{* * *} \\
(0.0047)\end{array}$ \\
\hline Consultant & $\begin{array}{c}0.5507^{* * *} \\
(0.0136)\end{array}$ & $\begin{array}{c}0.0083^{* *} \\
(0.0036)\end{array}$ & $\begin{array}{c}0.0048 \\
(0.0100)\end{array}$ & $\begin{array}{c}0.0609^{* * *} \\
(0.0091)\end{array}$ \\
\hline Accountant & $\begin{array}{c}0.7892^{* * *} \\
(0.0307)\end{array}$ & $\begin{array}{c}0.0219^{* *} \\
(0.0076)\end{array}$ & $\begin{array}{l}0.0250^{*} \\
(0.0172)\end{array}$ & $\begin{array}{c}0.1036^{* * *} \\
(0.0162)\end{array}$ \\
\hline Public Employee & $\begin{array}{c}-0.6132^{* * *} \\
(0.0373)\end{array}$ & $\begin{array}{c}-0.0282^{* * *} \\
(0.0077)\end{array}$ & $\begin{array}{c}0.0064 \\
(0.0387)\end{array}$ & $\begin{array}{c}-0.1061^{* * *} \\
(0.0278)\end{array}$ \\
\hline Tertiary Education & $\begin{array}{c}0.0648^{* * *} \\
(0.0094)\end{array}$ & $\begin{array}{c}0.0036 \\
(0.0024)\end{array}$ & $\begin{array}{c}0.0626^{* * *} \\
(0.0060)\end{array}$ & $\begin{array}{l}-0.0054 \\
(0.0046)\end{array}$ \\
\hline Business Degree & $\begin{array}{c}0.2198^{* * *} \\
(0.0098)\end{array}$ & $\begin{array}{c}0.0085^{* *} \\
(0.0025)\end{array}$ & $\begin{array}{c}0.0345^{* * * * *} \\
(0.0062)\end{array}$ & $\begin{array}{c}0.0449^{* * *} \\
(0.0054)\end{array}$ \\
\hline Law Education & $\begin{array}{c}0.3561^{* * *} \\
(0.0309)\end{array}$ & $\begin{array}{c}0.0114 \\
(0.0079)\end{array}$ & $\begin{array}{c}0.0150 \\
(0.0191)\end{array}$ & $\begin{array}{c}0.0980^{* * *} \\
(0.0178)\end{array}$ \\
\hline IT Education & $\begin{array}{c}-0.1321^{* * *} \\
(0.0306)\end{array}$ & $\begin{array}{c}0.0097 \\
(0.0112)\end{array}$ & $\begin{array}{c}0.0159 \\
(0.0193)\end{array}$ & $\begin{array}{c}-0.0051 \\
(0.0156)\end{array}$ \\
\hline City & $\begin{array}{c}-0.0347^{* * *} \\
(0.0074)\end{array}$ & $\begin{array}{c}0.0017 \\
(0.0017\end{array}$ & $\begin{array}{c}0.0043 \\
(0.0039))\end{array}$ & $\begin{array}{c}0.0002 \\
(0.0035)\end{array}$ \\
\hline Inverse Mills & & $\begin{array}{c}0.0298^{* * *} \\
(0.0058)\end{array}$ & $\begin{array}{c}0.0707^{* * *} \\
(0.0185)\end{array}$ & $\begin{array}{c}0.1583^{* * *} \\
(0.0160)\end{array}$ \\
\hline Business150 & $\begin{array}{c}0.1570^{* * *} \\
(0.0169)\end{array}$ & & & \\
\hline County-Fixed Effects & Yes & Yes & Yes & Yes \\
\hline Year-Fixed Effects & Yes & Yes & Yes & Yes \\
\hline Observations & $2,684,706$ & 107,182 & 107,182 & 107,182 \\
\hline
\end{tabular}


Table 6: Differences in individual characteristics around the major kink in the tax code

\begin{tabular}{|c|c|c|c|}
\hline Range in SEK & $\begin{array}{l}{[-2,500} \\
+2,500]\end{array}$ & $\begin{array}{l}{[-5,000} \\
+5,000]\end{array}$ & $\begin{array}{l}{[-10,000} \\
+10,000]\end{array}$ \\
\hline Born in Sweden & 0.005 & 0.006 & 0.005 \\
\hline Gender & 0.007 & 0.017 & 0.010 \\
\hline Age & -0.374 & -0.086 & -0.271 \\
\hline Marital Status & 0.017 & $0.031^{* *}$ & 0.011 \\
\hline Consultant & -0.014 & -0.009 & -0.004 \\
\hline Accountant & 0.004 & 0.004 & 0.004 \\
\hline Public Employee & -0.001 & -0.001 & 0.000 \\
\hline Tertiary Education & -0.004 & 0.006 & 0.010 \\
\hline Business Degree & 0.013 & -0.009 & -0.009 \\
\hline Law Education & -0.001 & -0.001 & 0.000 \\
\hline IT Education & 0.005 & 0.005 & 0.001 \\
\hline City & 0.014 & -0.002 & 0.003 \\
\hline Capital Income & $-4,531$ & -303 & 4,278 \\
\hline Observations & 3,911 & 7,268 & 10,321 \\
\hline
\end{tabular}

Table 7: Effect of Crossing the State Tax Threshold on Take-up of Income Shifting

\begin{tabular}{|c|c|c|c|c|c|c|}
\hline & & & & & & \\
\hline & Shell Cor & porations & Low Turr & over CHC & Holdir & g CHC \\
\hline & Without & With & Without & With & Without & With \\
\hline & Controls & Controls & Controls & Controls & Controls & Controls \\
\hline$[-2,500$ & $0.0111^{* *}$ & $0.0162^{* * *}$ & $0.0202^{* *}$ & $0.0600 * * *$ & $0.0378 * * *$ & $0.1464^{* * *}$ \\
\hline$+2,500]$ & {$[0.0044]$} & {$[0.0059]$} & {$[0.0090]$} & {$[0.0229]$} & {$[0.0094]$} & {$[0.0446]$} \\
\hline$[-5,000$ & $0.0112^{* * *}$ & $0.0240 * * *$ & $0.0204^{* * *}$ & $0.0693^{* * *}$ & $0.0376 * * *$ & $0.1501^{* * *}$ \\
\hline$+5,000]$ & {$[0.0036]$} & {$[0.0063]$} & {$[0.0071]$} & {$[0.0180]$} & {$[0.0075]$} & {$[0.0296]$} \\
\hline$[-10,000$ & $0.0092^{* * *}$ & $0.0240 * * *$ & $0.0205^{* * *}$ & $0.0676^{* * *}$ & $0.0384^{* * *}$ & $0.1419^{* * *}$ \\
\hline$+10,000]$ & {$[0.0029]$} & {$[0.0060]$} & {$[0.0061]$} & {$[0.0147]$} & {$[0.0065]$} & {$[0.0226]$} \\
\hline
\end{tabular}


Table 8: Networks and Awareness of Income Shifting

This table presents logit regression results for establishment of income shifting firms. The dependent variable is a dummy variable equal to 1 if the individual sets up a shell corporation in year t. In columns 3 and 4 (columns 5 and 6 ), we use establishment of a low-turnover corporation (holding corporation) as the dependent variable. Our main independent variable of interest is the percentage of individuals in a municipality in year t-1 that participate in income shifting. As controls, we add socioeconomic variables (see Table 2), the inverse Mills ratio, and year fixed effects. Standard errors (shown in parentheses) allow for heteroskedasticity clustered at the individual level. ***, **, and * denote significance at the $1 \%, 5 \%$, and $10 \%$ levels, respectively.

\section{Shell Low Turnover \\ Corporations \\ Corporation}

(1) (2)
$(3)$
(4)

\section{Holding \\ Corporation}

(5)

(6)

\begin{tabular}{lcccccc}
\hline $\begin{array}{l}\text { Density Shell } \\
\text { Corporations } t-1\end{array}$ & $1.4646^{* *}$ & & & & \\
Density Low & $(0.6887)$ & & & & \\
Turnover Corp.t-1 & & & $0.4818^{* * *}$ & & \\
Density Holding & & & $(0.0676)$ & & $0.4015^{* *}$ & \\
Corporations $t-1$ & & & & & $(0.1708)$ & \\
$\begin{array}{l}\text { Density Income } \\
\text { Shifters } t-1\end{array}$ & & $0.2339^{* *}$ & & $0.3192^{* * *}$ & & $0.1563^{* *}$ \\
\hline Baseline Controls & Yes & Yes & Yes & Yes & Yes & Yes \\
Year-FE & Yes & Yes & Yes & Yes & Yes & Yes \\
Observations & $2,684,706$ & $2,684,706$ & $2,684,706$ & $2,684,706$ & $2,684,706$ & $2,684,706$ \\
\hline
\end{tabular}

